\title{
Hypoglycaemic coma associated with gastric carcinoma
}

\author{
Iain C. Macdougall, Stewart Fleming and Brian M. Frier \\ Departments of Medicine and Pathology, Gartnavel General Hospital and Western Infirmary, Glasgow, UK.
}

\begin{abstract}
Summary: Gastric carcinoma may rarely be the cause of tumour-associated hypoglycaemia. We report the case of an elderly woman who presented in hypoglycaemic coma, and who was found subsequently to have an adenocarcinoma of the stomach. Hypoglycaemia persisted despite prednisolone, diazoxide, and a high concentration dextrose infusion. The few published cases are reviewed in which an association was established between gastric carcinoma and hypoglycaemia, and the possible aetiology of the hypoglycaemia is discussed.
\end{abstract}

\section{Introduction}

Hypoglycaemia is an uncommon but well-recognized complication of many tumours, and may rarely be the presenting feature. While pancreatic islet-cell tumours produce hypoglycaemia by the autonomous secretion of insulin, the mechanism by which extra-pancreatic tumours cause hypoglycaemia is less clear. Since the first case of hypoglycaemia associated with a hepatoma was described (Elliot, 1929), numerous reports have appeared of hypoglycaemia associated with other non-islet cell tumours. Of the cases reviewed by Kahn in 1980, 45\% were due to sarcoma and $23 \%$ to hepatoma. Hypoglycaemia associated with adrenocortical carcinoma (10\%), gastrointestinal $(8 \%)$ and haematological malignancies $(6 \%)$ was much less common. The purposes of this paper are to report a patient with gastric carcinoma whose presenting feature was hypoglycaemic coma, and to review the possible mechanisms underlying this metabolic disturbance.

\section{Case report}

A 69 year old housewife who had been previously well was found in bed in a trance-like state, and was comatose on arrival at hospital. Her capillary blood glucose [BM Strips (20-800R)] was less than $2 \mathrm{mmol} / 1$, but she regained consciousness after $25 \mathrm{~g}$ of dextrose was given intravenously. Systematic enquiry revealed symptoms of progressive fatigue, dyspepsia, dysphagia for solids, constipation, and weight loss of one stone over the preceding 9 months. On examination she looked pale and unwell, and an enlarged irregular

Correspondence: I.C. Macdougall B.Sc., MB, ChB.

Accepted: 20 February 1986 liver was easily palpable. Neurological examination was normal after consciousness had been regained.

Laboratory tests showed an iron deficiency anaemia with haemoglobin $9.4 \mathrm{~g} / \mathrm{dl}$ and hypochromic, microcytic red cells. Serum urea and electrolytes were normal but liver function tests were deranged. Abdominal ultrasonography confirmed the hepatomegaly and showed extensive hepatic metastases. A barium meal demonstrated a tumour in the gastric fundus with involvement of the lower oesophagus. Hepatic and oesophageal biopsies showed a poorly-differentiated adenocarcinoma, with no membrane-bound secretory granules on electron microscopy. Immunocytochemistry of the tumour tissue was positive for gastrin, somatostatin, and neurone-specific enolase, but was negative for insulin, pancreatic polypeptide and glucagon.

Endocrinological investigations yielded a low plasma insulin of $1.4 \mathrm{mU} / 1$ (normal $<15 \mathrm{mU} / \mathrm{l}$ ) and a plasma C-peptide concentration of $0.03 \mathrm{pmol} / 1$ (normal range: $0.18-0.63 \mathrm{pmol} / \mathrm{l})$ during an episode of clinical hypoglycaemia. Plasma cortisol, ACTH, gastrin, VIP, somatostatin (assayed by standard radioimmunoassay techniques) and tryptophan (measured by column chromotography) were all normal. Pancreatic polypeptide was moderately elevated at $348 \mathrm{pmol} / 1$ (normal $<300 \mathrm{pmol} / \mathrm{l}$ ), but both growth hormone $(1.7 \mathrm{mU} / \mathrm{l})$ and glucagon $(13 \mathrm{pmol} / \mathrm{l})$, which were measured during hypoglycaemia, were lower than expected, and a somatomedin $\mathrm{C}$ measurement was also low at $0.12 \mathrm{U} / \mathrm{ml}$ (normal range: 0.4$2.0 \mathrm{U} / \mathrm{ml}$ ).

The patient remained hypoglycaemic despite diazoxide, high dose prednisolone, and a high carbohydrate diet (Figure 1). A continuous intravenous infusion of $10 \%$ dextrose ( 3 litres per 24 hours) 


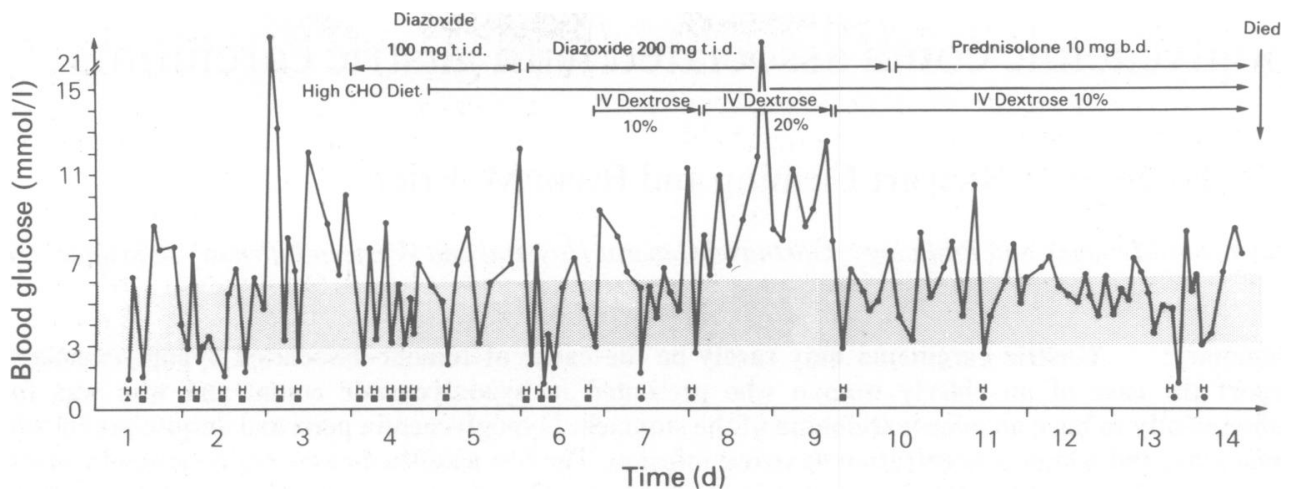

Figure 1 Serial capillary blood glucose concentrations, and the effect of various forms of treatment on the frequency of hypoglycaemic episodes. $\mathrm{H}=$ Hypoglycaemic episode; $\Delta=25 \mathrm{~g}$ dextrose i.v. bolus; $\square=50 \mathrm{~g}$ dextrose orally; = rate of i.v. dextrose infusion increased.

reduced the frequency of hypoglycaemic episodes which were abolished only by increasing the concentration of dextrose to $20 \%$. Her general condition deteriorated rapidly with the development of ascites, cardiac and renal failure, and she died 14 days after admission. At autopsy, a large, necrotic, fungating tumour was present at the upper end of the stomach extending into the oesophagus, with metastases in the liver (replacing approximately $30 \%$ of normal tissue), and the perigastric lymphnodes. The total tumour mass weighed approximately $2 \mathrm{~kg}$. The biliary tree, pancreas, pituitary, lungs, and adrenal glands were normal. Histology showed infiltration of the entire thickness of the stomach wall by a necrotic adenocarcinoma which in some areas appeared to be anaplastic, while in others the appearances were those of a mucussecreting adenocarcinoma. The hepatic metastases were histologically similar to the primary tumour, but there was substantial preservation of the liver parenchyma, with glycogen present in the hepatocytes.

\section{Discussion}

This is a distinctly unusual case both because of its mode of presentation and the rarity of hypoglycaemia in association with gastric carcinoma. Characteristically, tumour-associated hypoglycaemia occurs after periods of fasting as a late manifestation of a previously diagnosed tumour, although occasionally, as in the

Table 1 Summary of previously published cases of gastric carcinoma associated with hypoglycaemia

\begin{tabular}{|c|c|c|c|c|c|}
\hline & $\begin{array}{l}\operatorname{Age}(y) / \\
\quad \operatorname{Sex}\end{array}$ & Metastases & $\begin{array}{l}\text { Presenting } \\
\text { symptoms }\end{array}$ & $\begin{array}{l}\text { Plasma insulin, insulin-like } \\
\text { activity }(I L A) \& \text { growth hormone }(G H)\end{array}$ & References \\
\hline (1) & $?$ & $\mathbf{H}$ & $?$ & - & Bielschowsky (1932) \\
\hline (2) & $?$ & $\mathbf{H}$ & $?$ & 个insulin, 个ILA & Goldner (1961) \\
\hline (3) & $55 \mathrm{M}$ & $\mathbf{H}$ & abdominal pain & - & Gonzales et al. (1963) \\
\hline (4) & $57 \mathrm{M}$ & $\mathbf{H}, \mathbf{N}$ & $\begin{array}{l}\text { abdominal pain, } \\
\text { vomiting }\end{array}$ & normal ILA & Gonzales et al. (1963) \\
\hline (5) & $59 \mathrm{~F}$ & $\mathbf{H}$ & hypoglycaemic coma & $\begin{array}{c}\text { normal insulin, } \\
\downarrow \mathrm{GH}\end{array}$ & Marks et al. (1965) \\
\hline (6) & $64 \mathrm{M}$ & $\mathbf{N}$ & dysphagia & - & Silverstein et al. (1966) \\
\hline (7) & $66 \mathrm{M}$ & $\mathrm{H}, \mathbf{N}$ & anorexia, anaemia & normal insulin & Miyabo et al. (1968) \\
\hline (8) & $84 \mathrm{~F}$ & H,L & $\begin{array}{l}\text { right hypochondrial } \\
\text { pain }\end{array}$ & - & $\begin{array}{l}\text { De Leeuw \& De Leeuw } \\
\text { (1971) }\end{array}$ \\
\hline (9) & $76 \mathrm{M}$ & $\mathbf{H}, \mathbf{P}$ & ventricular tachycardia & normal insulin & Miley et al. (1975) \\
\hline (10) & $65 \mathrm{M}$ & H,L,P & hypoglycaemic coma & $\begin{array}{c}\text { normal insulin, normal ILA, } \\
\text { normal GH }\end{array}$ & Tamburrano et al. (1979) \\
\hline
\end{tabular}

$\mathrm{H}=$ hepatic $\mathrm{L}=$ lung; $\mathrm{N}=$ lymph nodes; $\mathrm{P}=$ peritoneum; $\uparrow=$ increased levels; $\downarrow=$ decreased levels. 
present case, it may be the presenting feature of the neoplasm.

Only 10 cases of gastric carcinoma associated with hypoglycaemia have been described previously (Table I). All patients were middle-aged or elderly, and metastatic disease was uniformly present with hepatic involvement in nine, although in the two cases reported by Gonzales et al. (1963) invasion of the liver was minimal. Two subjects presented in hypoglycaemic coma; the others had symptoms attributable to the primary tumour.

Most extra-pancreatic tumours associated with hypoglycaemia are large, weighing from $400 \mathrm{~g}$ to $20 \mathrm{~kg}$ (Laurent et al., 1971). The total tumour bulk in the present case was approximately $2 \mathrm{~kg}$, neither this nor the degree of hepatic involvement being exceptional for gastric carcinoma.

The cause of hypoglycaemia induced by extra-pancreatic tumours is often uncertain, although Kahn (1980) has suggested three possible mechanisms: (1) secretion of insulin or an insulin-like substance by the tumour; (2) glucose consumption by the tumour; (3) failure of compensatory mechanisms to stimulate glycogenolysis or gluconeogenesis either via destruction of the liver by tumour, or by suppression of counter-regulatory hormonal secretion.

Plasma concentrations of insulin, C-peptide, and somatomedin $\mathrm{C}$ were low in the present case with no evidence of membrane-bound secretory granules on electron microscopy. Utilization of glucose by the tumour was not measured, but it seems improbable that this mechanism alone could account for the clinical presentation since the total mass of tumour was not exceptional. Similarly, gluconeogenesis was unlikely to be impaired by hepatic metastases since less than half of the liver was replaced by tumour and up to $75 \%$ of the normal liver may be removed without the development of hypoglycaemia (Unger, 1966). Moreover, although plasma concentrations of growth hormone and glucagon were low, the evidence is not convincing that impaired secretion of these counterregulatory hormones causes, rather than prolongs, hypoglycaemia (Kahn, 1980). A review of data from previous reports of gastric carcinoma with hypoglycaemia (Table I) also fails to provide a satisfactory explanation for hypoglycaemia in most cases.

Treatment of tumour-induced hypoglycaemia is usually ineffective. Excision of the tumour bulk may be of benefit if the patients can withstand surgery. Three cases of gastric carcinoma reported previously, underwent palliative surgery but this was of limited success in only one subject who had no metastases at laparotomy (Silverstein et al., 1966). Without operation, few patients survive for more than 3 months and death may occur within a few days of presentation. Hypoglycaemia therefore heralds a poor prognosis although this may simply be related to the advanced neoplasia. Diazoxide has been used successfully in the management of insulinoma, but has proved disappointing in treating the hypoglycaemia induced by extra-pancreatic tumours. An effective response to diazoxide was reported in one patient with gastric carcinoma (Tamburrano et al., 1979), but in our patient no hyperglycaemic response was obtained. Continuous intravenous infusion of hyperosmolar dextrose is usually a last resort in the management of these patients, and may prevent or alleviate the distressing symptoms of neuroglycopenia in the terminal stages of their disease.

\section{Acknowledgements}

We wish to thank Professor V. Marks and Dr D. Teale for assaying somatomedin C, Professor S.R Bloom for assaying gut peptides, Dr R.W. Logan for assaying plasma tryptophan, Dr G. Beastall for plasma insulin and C-peptide assays, and Dr I. Brown for the immunocytochemistry of tumour tissue. We are most grateful to Dr C. Isles for helpful suggestions with the manuscript and to Miss Alison Wood for secretarial assistance.

\section{References}

BIELSCHOWSKY, F. (1932). Zur klinik und pathologie der spoutan Hypoglykamie. Klinische Wochenschrift, 11, 1492.

DE LEEUW, I. \& DELVIGNE-DE LEEUW, C. (1971). Coma hypoglycémique récidivant associé à un carcinome gastrique. Le Diabete, 19, 47.

ELLIOTT, C.A. (1929). Hepatic hypoglycemia associated with primary liver cell carcinoma. Transactions of the Association of American Physicians, 44, 121.

GOLDNER, M.G. (1961). In discussion of Franz V.K.: Extrapancreatic tumors associated with hypoglycemia. Bulletin of the New York Academy of Medicine, 37, 73.

GONZALES, F.M., GOLD, G.L. \& SCHNIDER, B.I. (1963).
Gastrointestinal carcinoma and concomitant hypoglycemia. Annals of Internal Medicine, 58, 149.

KAHN, C.R. (1980). The riddle of tumour hypoglycaemia revisited. Clinics in Endocrinology and Metabolism, 9, 335.

LAURENT, J., DERBY, G. \& FLOQUET, J. (1971). In Hypoglycaemic Tumours. p.241. Excerpta Medica: Amsterdam.

MARKS, V., AULD, W.H.R. \& BARR, J.B. (1965). Carcinoma of stomach and other non-pancreatic lesions as causes of spontaneous hypoglycaemia. British Journal of Surgery, 52, 925.

MILEY, G.B., BINNICK, S.A. \& BLOCK, P.J. (1975). Hy- 
poglycemia and ventricular tachycardia due to adenocarcinoma of the stomach. American Journal of the Medical Sciences, 269, 403.

MIYABO, S., FUJIMURA, A., MATSUDA, T. \& MURAKAMI, M. (1968). Gastric cancer containing insulin and associated with hypoglycemia. Diabetes, 17, 286.

SILVERSTEIN, M.N., WAKIM, K.G., BAHN, R.C. \& DECKER, R.H. (1966). Role of tryptophan metabolites in the hy- poglycemia associated with neoplasia. Cancer, 19, 127. TAMBURRANO, G., TAMBURRANO, S., NATOLI, C., DI MARIO, U. \& ANDREANI, D. (1979). Gastric carcinoma associated with severe hypoglycemia sensitive to diazoxide. Diabete et Metabolisme, 5, 287.

UNGER, R.H. (1966). The riddle of tumor hypoglycemia (Editorial). American Journal of Medicine, 40, 325. 